\title{
Evaluation of Streptomyces spp. and Bacillus spp. for biocontrol of Fusarium wilt in chickpea (Cicer arietinum L.)
}

\author{
B. G. Anusha, S. Gopalakrishnan, M. K. Naik \& M. Sharma
}

To cite this article: B. G. Anusha, S. Gopalakrishnan, M. K. Naik \& M. Sharma (2019): Evaluation of Streptomyces spp. and Bacillus spp. for biocontrol of Fusarium wilt in chickpea (Cicer arietinum L.), Archives of Phytopathology and Plant Protection, DOI: 10.1080/03235408.2019.1635302

To link to this article: https://doi.org/10.1080/03235408.2019.1635302

曲 Published online: 08 Jul 2019.

Submit your article to this journal $₫$

山 Article views: 3

View Crossmark data $\complement$ 


\title{
Evaluation of Streptomyces spp. and Bacillus spp. for biocontrol of Fusarium wilt in chickpea (Cicer arietinum L.)
}

\author{
B. G. Anusha ${ }^{a, b, c}$, S. Gopalakrishnan ${ }^{b, c}$, M. K. Naik ${ }^{a, d}$ and M. Sharmab,c \\ ${ }^{a}$ Department of Plant Pathology, University of Agricultural Sciences, Raichur, Karnataka, India; \\ ${ }^{b}$ Biocontrol, International Crops Research Institute for the Semi-Arid Tropics (ICRISAT), \\ Patancheru, Telangana, India; 'Pathology, International Crops Research Institute for the Semi- \\ Arid Tropics (ICRISAT), Patancheru, Telangana, India; ${ }^{d}$ Department of Plant Pathology, \\ University of Agricultural and Horticultural Sciences, Shivamogga, Karnataka, India
}

\begin{abstract}
A study was carried out to test direct and indirect antagonistic effect against Fusarium wilt, caused by Fusarium oxysporum f. sp. ciceri (FOC), and plant growth-promoting (PGP) traits of bacteria isolated from rhizosphere soils of chickpea (Cicer arietinum L.). A total of 40 bacterial isolates were tested for their antagonistic activity against FOC and of which 10 were found to have strong antagonistic potential. These were found to be Streptomyces spp. (five isolates) and Bacillus spp. (five isolates) in the morphological and biochemical characterisation and 16S rDNA analysis. Under both greenhouse and wilt sick field conditions, the selected Streptomyces and Bacillus isolates reduced disease incidence and delayed expression of symptoms of disease, over the non-inoculated control. The PGP ability of the isolates such as nodule number, nodule weight, shoot weight, root weight, grain yield and stover yield were also demonstrated under greenhouse and field conditions over the non-inoculated control. Among the ten isolates, Streptomyces sp. AC-19 and Bacillus sp. BS-20 were found to have more potential for biocontrol of FOC and PGP in chickpea. This investigation indicates that the selected Streptomyces and Bacillus isolates have the potential to control Fusarium wilt disease and to promote plant growth in chickpea.
\end{abstract}

\section{ARTICLE HISTORY}

Received 18 September 2018 Revised 22 March 2019

Accepted 7 June 2019

Published online 2 July 2019

\section{KEYWORDS}

Antagonistic bacteria; biocontrol; chickpea; Fusarium wilt; Fusarium oxysporum f. sp. ciceri; Streptomyces spp.; Bacillus spp

\section{Introduction}

Fusarium wilt caused by F. oxysporum Schl. emend. Snyd. and Hans. f. sp. ciceri (Padwick; Fusarium oxysporum f. sp. ciceri (FOC)) is the third most important disease in chickpea (Cicer arietinum L.) throughout the world. It is one of the main yield-limiting factors in all chickpea-growing

CONTACT S. Gopalakrishnan s.gopalakrishnan@cgiar.org D Department of Plant Pathology, University of Agricultural Sciences, Raichur 585 204, Karnataka, India

(C) 2019 Informa UK Limited, trading as Taylor \& Francis Group 
areas of the world (Dubey et al. 2007). General symptoms of Fusarium wilt in chickpea include drooping, yellowing, drying of the leaves and discolouration of vascular system. The pathogen infects the roots of susceptible host, colonises the vascular system of plants and produces toxin(s) that kills plants by blocking xylem vessels and restricts water transport (Anjaiah et al. 2003; Gopalakrishnan et al. 2005). FOC can survive saprophytically in the soil or crop debris for more than six years (Trapero-Casas and Jimenez-Diaz 1985). Therefore, it is not possible to control by normal crop rotation. The use of resistant cultivar is the most efficient control measure but the effectiveness of resistance is restricted by the occurrence of eight pathogenic races in FOC (Jimenez-Gasco et al. 2002). Application of fungicides does not always prove economical against soil-borne pathogens and it has also led to environmental pollution, pathogen resistance, increased risk to human and animal health and creates an imbalance in the microbial community in soil ( $\mathrm{Li}$ et al. 2012; On et al. 2015).

The use of microbial biocontrol agents is an alternative to fungicides for the management of plant diseases because it is one of the most environmentally viable and health-friendly approaches for replacing fungicides (Jiménez-Fernández et al. 2015). Numerous biocontrol agents have been reported to control Fusarium wilt of chickpea, such as Pseudomonas fluorescens, Bacillus subtilis, Trichoderma spp. and Streptomyces spp. (Gopalakrishnan et al. 2011; Moradi et al. 2012). Different mechanisms have been implicated in the suppression of fungal root diseases by biocontrol agents such as competition for nutrients and production of microbial metabolites such as extracellular antibiotics, siderophores, lytic enzymes and hydrogen cyanide (Das et al. 2008; Naureen et al. 2009; Erdogan and Benlioglu 2010). Such plant growth-promoting (PGP) microbes facilitate plant growth either directly by nitrogen fixation, phosphate solubilisation, iron chelation and phytohormone production (Cakmakci et al. 2006; Vivas et al. 2006; Hanane et al. 2008) or indirectly by inhibiting phytopathogens, and thus promoting plant growth and development. Biocontrol agents are known to be found commonly in forest soil, pasture soil, rhizosphere soil and compost/vermicompost.

Actinobacteria are Gram-positive bacteria with high GC content in their genome and resemble fungi morphologically. Among actinobacteria, Streptomyces is the predominant genus followed by Actinomadura, Actinoplanes, Frankia, Microbispora, Micromonospora, Nocardia, Mycobacterium, Nonomurea, Saccharopolyspora and Verrucosispora and they found commonly in soil (Gopalakrishnan et al. 2016). Actinobacteria are also known for production of secondary metabolites and of which the genus, Streptomyces, is the major producer (39\%) of secondary metabolites, including 
antibiotics, anticancer agents, antiparasitic drugs, antifungals, antivirals, immune suppressants, insecticides, antioxidants, enzyme inhibitors and herbicides (Berdy 2012). Bacillus is another important PGP bacteria that has been found naturally in the rhizosphere soils and reported widely in promoting not only plant growth and yield but also antagonistic against phytopathogens (Sreevidya and Gopalakrishnan 2017). The main objective of the present study was to isolate Streptomyces spp. and Bacillus spp. from rhizosphere soils of chickpea and to evaluate further for their antagonistic potential against Fusarium wilt disease of chickpea under in vitro, greenhouse and field conditions.

\section{Material and methods}

\section{Isolation of actinomycetes and Bacillus spp.}

Rhizosphere soil samples were collected, at the depth of $0-15 \mathrm{~cm}$, with the help of soil core, randomly in the chickpea fields of International Crops Research Institute for the Semi-Arid Tropics (ICRISAT), Patancheru, India. Ten grams of rhizosphere soil was added in a conical flask containing $90 \mathrm{~mL}$ of physiological saline $(0.85 \% \mathrm{NaCl}$; in order to provide osmotic protection for bacterial cells in the sample) and kept for shaking on an orbital shaker (at $100 \mathrm{rpm}$ ) at $28 \pm 2{ }^{\circ} \mathrm{C}$ for $1 \mathrm{~h}$. At the end of shaking, the samples were serially diluted up to $10^{6}$ dilutions. Dilutions $10^{4}-10^{6} \mathrm{dilu}-$ tions were spread plated $(0.1 \mathrm{~mL})$ on actinomycetes isolation agar (AIA; HiMedia Laboratories, Mumbai, India) for isolating actinomycetes and Bacillus differential agar (BDA; composition: yeast autolysate - $0.2 \mathrm{~g}$, mannitol - $5.0 \mathrm{~g}$, monohydrogen ammonium phosphate - $1.0 \mathrm{~g}$, potassium chloride - $0.2 \mathrm{~g}$, magnesium sulphate - $0.2 \mathrm{~g}$, bromocresol purple $0.0075 \mathrm{~g}$, agar $15 \mathrm{~g}$, final $\mathrm{pH} 7.2 \pm 0.2$ ) for isolating Bacillus spp. The plates were incubated at $28 \pm 2{ }^{\circ} \mathrm{C}$ for 7 days for actinomycetes and 2 days for Bacillus spp. Prominent colonies were isolated, purified (by picking isolated colonies) and stored on AIA or BDA slants at $4^{\circ} \mathrm{C}$ for further studies.

\section{In vitro antagonistic activity against FOC}

The prominent actinomycetes and Bacillus isolates were screened for their antagonistic activity against FOC (acquired from legume pathology, ICRISAT, Patancheru, India) by dual-culture assay on glucose cassamino acid yeast extract (GCY) agar as per the protocols of Gopalakrishnan et al. (2011). In brief, a disc of FOC (6 mm dia.) was placed on one edge ( $1 \mathrm{~cm}$ from the corner) of the GCY agar plate and actinomycetes/Bacillus spp. was streaked on the other edge of the plate $(1 \mathrm{~cm}$ from the corner). 
The plates were incubated at $28 \pm 2{ }^{\circ} \mathrm{C}$ for 5 days. Inhibition of the FOC was recorded as positive and the inhibition zone measured.

\section{Enzymatic activities and secondary metabolite production by the selected actinomycetes and Bacillus isolates}

The selected isolates were evaluated for their production of siderophore, cellulase, protease, lipase, hydrocyanic acid (HCN), indole acetic acid (IAA) and $\beta$-1, 3-glucanase. Siderophore production was estimated as per the protocol of Schwyn and Neilands (1987). Production of cellulase and protease and lipase was detected by using standard protocols of Hendricks et al. (1995) and Bhattacharya et al. (2009), respectively. HCN was qualitatively assessed by the method described by Lorck (1948). Estimation of IAA and $\beta$-1,3-glucanase was done as per the protocols of Patten and Glick (1996) and Singh et al. (1999), respectively. The rating scales for cellulase, lipase and protease were as follows: $0=$ no halo zone; $1=$ halo zone of $1-10 \mathrm{~mm} ; 2=$ halo zone of $11-20 \mathrm{~mm} ; 3=$ halo zone of $21-30 \mathrm{~mm}$; $4=$ halo zone of $31-40 \mathrm{~mm}$; and $5=41-50 \mathrm{~mm}$. For $\mathrm{HCN}$ production, the following rating scale was used: $0=$ no colour change, $1=$ light reddish brown, $2=$ medium reddish brown and $3=$ dark reddish brown.

\section{Molecular identification of actinomycetes and Bacillus isolates}

Pure cultures of the selected antagonistic actinomycetes and Bacillus isolates were sent to Macrogen Inc. Seoul, Korea for identification based on their $16 \mathrm{~S}$ rDNA analysis. Macrogen used universal bacterial primers $27 \mathrm{~F}$ (5'-AGAGTTTGATCMTGGCTCAG-3') and $1492 \mathrm{R}$ (5'TACGGYTACCTTGTTACGACTT-3') for amplification of the $16 \mathrm{~S}$ rDNA gene (Bazzicalupo and Fani 1995). The obtained sequences were compared with similar sequences retrieved from GenBank (using the BLAST program and aligned using the Clustal W software) and the dendrogram was constructed by the neighbour-joining method (Saitou and Nei 1987; Alschul et al. 1990; Thompson et al. 1997). Bootstrap analysis was performed using the MEGA version 4 program to estimate the statistical stability of the branches in cluster with 1000 replications. The sequences were submitted to NCBI and accession numbers obtained.

\section{Antagonistic and PGP potentials of the selected actinomycetes and Bacillus isolates under greenhouse conditions}

The five most potential antagonistic actinomycetes and Bacillus isolates against FOC, from the in vitro studies, were evaluated individually for 
their antagonistic potential in pots in the greenhouse. Pot mixture was prepared by mixing Vertisol, sand and farm yard manure at 3:2:1 (w/w) and was filled $(1 \mathrm{~kg})$ in 8 in. plastic pots (Hosco Horticultural Supplies Co, Mumbai, India) followed by inoculation with FOC inoculum (20\% of pot weight, $200 \mathrm{~g} \mathrm{pot}^{-1}$; two weeks before sowing). FOC inoculum was mass-multiplied on chickpea grains (variety JG62; highly susceptible to Fusarium wilt, acquired from the Legumes Pathology Division, ICRISAT) as per the methodology of Gopalakrishnan et al. (2011). Inoculum was thoroughly mixed with the pot mixture and the pots were covered with polythene sheets, in order to maintain the moisture in the soil so that inoculum will be developed. The whole setup was incubated at $26 \pm 2{ }^{\circ} \mathrm{C}$ for 15 days to have Fusarium wilt disease conditions. Two weeks later, the seeds of chickpea variety JG62 were surface-sterilised (with $2.5 \%$ sodium hypochlorite solution in water for $5 \mathrm{~min}$ and rinsed 8 times with sterilised double distilled water) and treated with respective actinomycetes/Bacillus. Each actinomycetes/Bacillus isolates were inoculated by three different methods, namely $\mathrm{M} 1=$ inoculation of the seeds by soaking in the respective actinomycetes/Bacillus culture for $1 \mathrm{~h}$; $\mathrm{M} 2$ = inoculation of the potting mixture with actinomycetes/Bacillus culture at the time of sowing $\left(10 \mathrm{ml}\right.$ of well-grown culture $\left[10^{8} \mathrm{CFU} \mathrm{ml}{ }^{-1}\right]$ applied on the seed and covered with soil; CFU was obtained by spread plating the actinomycetes/Bacillus culture on AIA/BDA plates) and $\mathrm{M} 3=\mathrm{M} 1+\mathrm{M} 2$. Six inoculated seeds were sown (at $2-3 \mathrm{~cm}$ depth) in each pots and one week later thinned to retain three seedlings. The experiment had six replications. Plants were irrigated once every two days with $20 \mathrm{ml}$ of sterilised distilled water. Incidence of Fusarium wilt disease (number of plants showing wilt symptoms to the total number of plants in a pot) was recorded on 5, 10, 15, 20 and 29 days after sowing (DAS). Disease incidence was calculated using the method reported by Cao et al. (2011) with the following formula:

Disease incidence $(\%)=$ Number of diseased plants/Total number of plants $\times 100$

The selected five Streptomyces and Bacillus isolates were also evaluated for their PGP traits under greenhouse conditions. Soil mixture containing Vertisol, sand and farm yard manure (3:2:1) was prepared and filled in plastic pots $\left(8^{\prime \prime}\right)$. A total of 13 treatments (five Streptomyces isolates + their consortia, five Bacillus isolates + their consortia and one uninoculated control) with three replications were maintained. The seeds of chickpea variety JG11 were surface-sterilised and treated with respective Streptomyces/Bacillus isolates as described earlier. Six seeds were sown (at $2-3 \mathrm{~cm}$ depth) in each pots and one week later thinned to retain three seedlings. The experiment had six replications. At the seven days 
interval, a booster (additional) dose of Streptomyces/Bacillus was added. At 30 DAS, PGP traits including plant height, branches number, pod number, nodule number, nodule weight, leaf area, leaf weight, root weight, stem weight, total plant weight, surface area, root length and root volume were recorded. At 45 DAS, observation recorded including plant height, branches number, nodule number, nodule weight, flower number, pod number, root weight, stem weight, leaf weight and total plant weight and at harvesting, pod number, pod weight, shoot weight, seed number and seed weight were recorded.

\section{Field studies}

Field trials were performed in 2016 and 2017 post-rainy seasons at ICRISAT, Patancheru $\left(17^{\circ} 30.861^{\prime} \mathrm{N} ; 78^{\circ} 16.080^{\prime} \mathrm{E}\right.$; altitude $\left.=549 \mathrm{~m}\right)$ in the Telangana State of India. The experimental field soils are classified as $51 \%$ clay, $22 \%$ silt and $26 \%$ sand with an organic carbon content of $0.4-0.5 \%$ and an alkaline $\mathrm{pH}$ of $7.5-8.1$. The mineral content of the experimental field rhizosphere soil (top $15 \mathrm{~cm}$ ) includes $24 \mathrm{mg} \mathrm{kg}^{-1}$ soil of available nitrogen, $8 \mathrm{mg} \mathrm{kg}^{-1}$ soil of available phosphorous and $294 \mathrm{mg} \mathrm{kg}^{-1}$ soil of available potassium. The experimental field was kept fallow except for post-rainy season. The maximum and minimum temperatures recorded during the cropping season were 29.01-32.71 and 12.05- 14.43, respectively. The experimental plots were laid out of $4 \mathrm{~m} \times 3 \mathrm{~m}$ ridges (rows) arranged in a randomised complete block design with three replications.

Three genotypes of chickpea (JG62 and K850 - susceptible to Fusarium wilt, early and later wilter, respectively; JG11- popular cultivar) were surface-sterilised, treated with respective Streptomyces/Bacillus isolates, as described earlier, and sown by hand at $5 \mathrm{~cm}$ depth. A booster doses of Streptomyces/Bacillus peat-based formulation $\left(10^{8} \mathrm{cfu} \mathrm{ml} \mathrm{m}^{-1}\right)$ were applied to soil at an interval of 15 DAS until flowering stage. Control plots were maintained without the application of Streptomyces/Bacillus. Weeding was performed as and when required. No serious insect pest or phytopathogens (except FOC) were observed during the cropping period. During the cropping season, a maximum temperature range of 27.1$31.0^{\circ} \mathrm{C}$ and a minimum temperature range of $7.0-19.2^{\circ} \mathrm{C}$ were recorded. Incidence of Fusarium wilt (number of plants showing wilt symptoms to total number of plants in a plot) was recorded in JG62 on 18, 22 and 26 DAS and in K850 on 45, 58 and 75 DAS till the susceptible check showed close to $100 \%$ mortality.

In JG11 cultivar, at 35 DAS, PGP traits, including plant height, nodule number, nodule weight, leaf area, leaf weight and stem weight were 
recorded. At 60 DAS, plant height, nodule number, nodule weight, shoot weight, pod number and pod weight and while at final harvest, pod number, pod weight, seed number, stover weight and grain weight were recorded. The roots of chickpea were tested for colonisation by Streptomyces and Bacillus spp. by SEM analysis (Gopalakrishnan et al. 2015). The samples were examined with a scanning electron microscope (JOEL-JSM 5600) as per the standardised procedure at RUSKA lab, College of Veterinary Science, Rajendranagar, Hyderabad, India. Observations of the presence of Streptomyces and Bacillus spores/cell on root surfaces were recorded.

\section{Statistical analysis}

The data were subjected to analysis of variance (ANOVA) (GenStat 10.1 version 2007, Lawes Agricultural Trust, Rothamsted Experimental Station) to evaluate the efficiency of biocontrol agent's application in both the greenhouse and field studies. Significance of differences between the treatment means was tested at $p=0.01$ and 0.05 .

\section{Results}

\section{Selection of antagonistic actinomycete and Bacillus isolates against FOC}

A total of 20 actinomycete and 20 Bacillus isolates, the most prominent ones which were found abundantly and inhibited the adjacent colonies, were isolated from AIA and BDA, respectively, and further screened for their antagonistic potential against FOC by dual-culture assay. The five most potential FOC antagonistic actinomycetes (AC-5, AC-6, AC-10, AC-18 and AC-19) and Bacillus (BS-10, BS-15, BS-17, BS-19 and BS-20) isolates were selected for further evaluation. Of the selected 10 FOC antagonistic isolates, BS-20 inhibited the most (inhibition zone $29 \mathrm{~mm}$ ) followed by AC-5 $(27 \mathrm{~mm})$ and AC-10 $(25 \mathrm{~mm})$ (Figure 1).

\section{Enzymatic activities and secondary metabolite production by the selected actinomycetes and Bacillus isolates}

All the selected actinomycete and Bacillus isolates were found to produce cellulase (except AC-5), protease (except AC-5, AC-10 and BS-10), lipase (except AC-5), HCN (except AC-18 and BS-10), IAA and $\beta-1,3$-glucanase. Siderophore was produced only by four isolates (AC-10, AC-18, BS-15 and BS-20). Of the selected 10 FOC antagonistic isolates, only BS20 was found to produce all the traits (Table 1). 


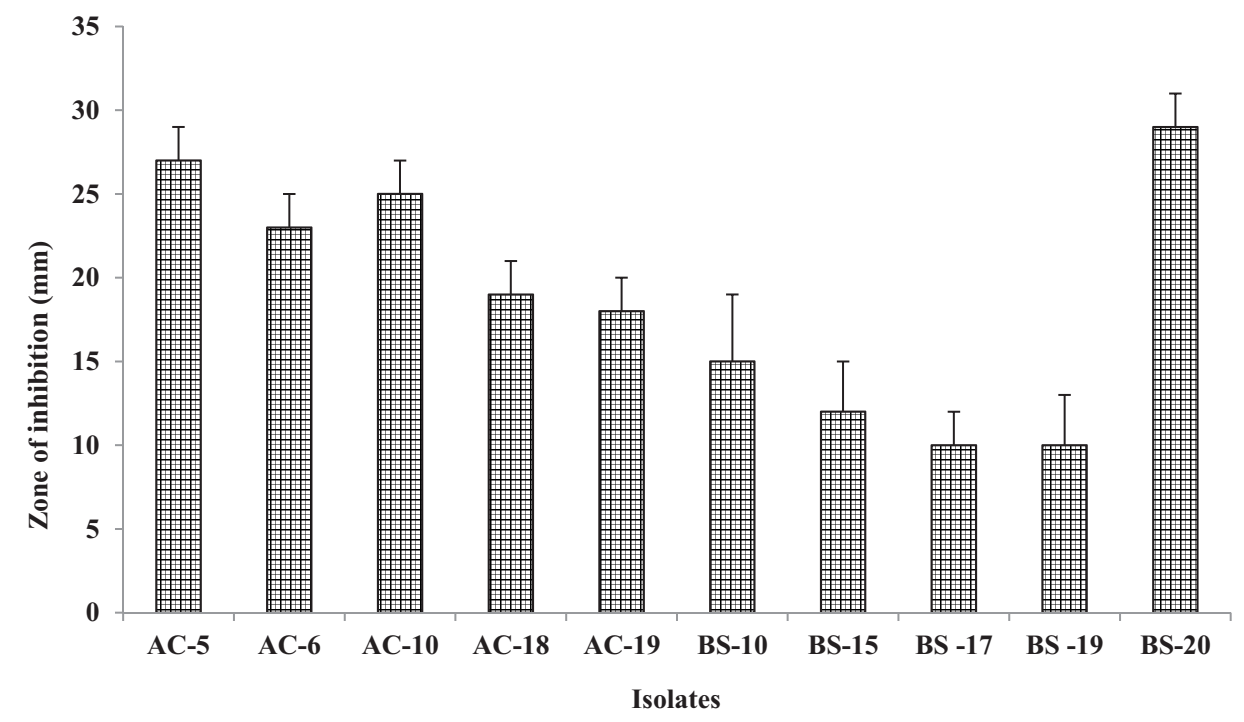

Figure 1. In vitro antagonistic activity of actinomycetes and Bacillus isolates against FOC.

Table 1. In vitro evaluation of actinomycetes and Bacillus isolates for different PGP traits.

\begin{tabular}{|c|c|c|c|c|c|c|c|}
\hline Isolate & Cellulase & Protease & Lipase & $\begin{array}{c}\text { Siderophore } \\
\text { (\% units) }\end{array}$ & $\mathrm{HCN}$ & $\begin{array}{c}\text { IAA } \\
\left(\mu \mathrm{gml}^{-1}\right)\end{array}$ & $\begin{array}{c}\beta-1,3-\text { glucanase } \\
\text { units }^{\mathrm{a}}\end{array}$ \\
\hline AC-5 & 0 & 0 & 0 & 0.0 & 1 & 2.4 & 0.28 \\
\hline AC-6 & 1 & 1 & 3 & 0.0 & 1 & 10.1 & 2.08 \\
\hline$A C-10$ & 2 & 0 & 2 & 51.5 & 2 & 31.6 & 0.77 \\
\hline$A C-18$ & 2 & 2 & 3 & 54.0 & 0 & 9.8 & 2.08 \\
\hline AC-19 & 2 & 2 & 3 & 0.0 & 2 & 12.2 & 2.15 \\
\hline BS-10 & 3 & 0 & 2 & 0.0 & 0 & 14.1 & 0.18 \\
\hline BS-15 & 3 & 2 & 2 & 16.5 & 1 & 12.5 & 1.29 \\
\hline BS-17 & 3 & 1 & 1 & 0.0 & 2 & 10.8 & 1.01 \\
\hline BS-19 & 3 & 1 & 1 & 0.0 & 2 & 23.0 & 1.34 \\
\hline BS-20 & 3 & 2 & 3 & 23.5 & 2 & 25.0 & 1.72 \\
\hline SE \pm & 0.39 & 0.30 & 0.27 & 0.31 & 0.14 & 1.57 & 0.30 \\
\hline LSD (1\%) & 1.29 & 0.97 & 0.89 & 0.97 & 0.44 & 5.11 & 0.97 \\
\hline
\end{tabular}

${ }^{a}$ One units of $\beta$-1,3-glucanase activity was defined as the amount of enzyme that liberated $1 \mu \mathrm{g} \mathrm{ml}$ of glucose hour $^{-1}$ at defined conditions.

HCN: Hydrocyanic acid; IAA: Indole acetic acid.

The rating scales for cellulase, lipase and protease were as follows: $0=$ no halo zone; $1=$ halo zone of $1-10 \mathrm{~mm} ; 2=$ halo zone of $11-20 \mathrm{~mm} ; 3=$ halo zone of $21-30 \mathrm{~mm} ; 4=$ halo zone of $31-40 \mathrm{~mm}$; and $5=41-50 \mathrm{~mm}$. For HCN production, the following rating scale was used: $0=$ no colour change, $1=$ light reddish brown, 2 = medium reddish brown and $3=$ dark reddish brown.

\section{Molecular identification of the selected actinomycete and Bacillus isolates}

When the sequences of the selected actinomycetes (AC-5, AC-6, AC-10, AC18 and AC-19) and Bacillus (BS-10, BS-15, BS-17, BS-19 and BS-20) isolates were analysed, the results revealed that all actinomycetes matched (100\%) with Streptomyces but different species (such as S. warrensis, S. phaeopurpureus, S. atrovirens, S. griseorubens and S. parvus, respectively) while the Bacillus isolates matched (100\%) with Bacillus but different species (such as 
(a)

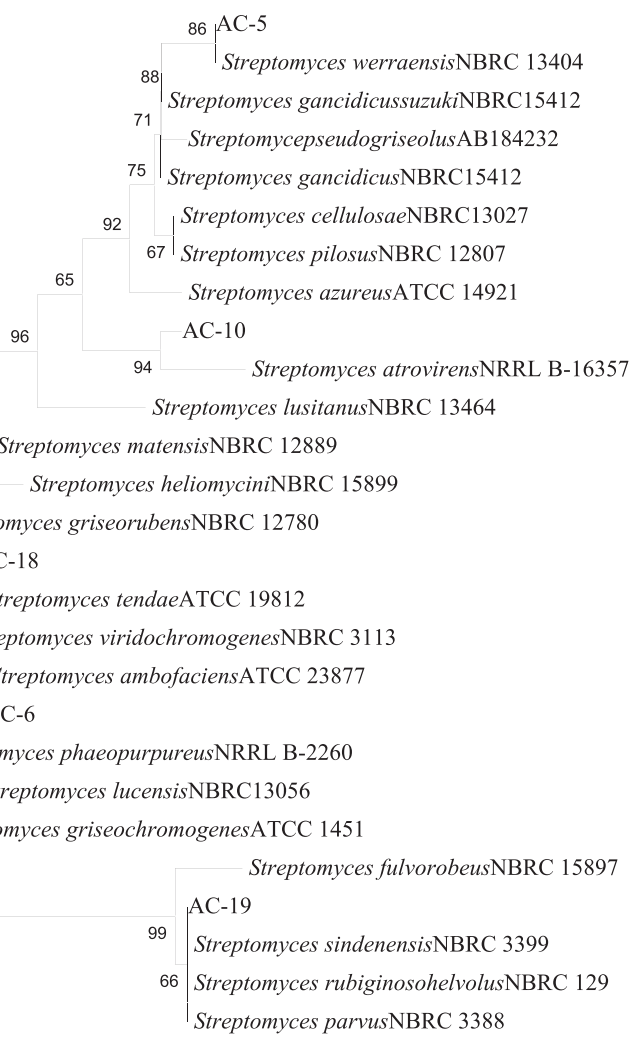

eptomyces matensis NBRC 12889

Streptomyces phaeopurpureusNRRL B-2260

Streptomyces lucensis NBRC13056 Streptomyces griseochromogenesATCC 1451

Streptomyces rubiginosohelvolus NBRC 129

treptomyces parvus NBRC 3388

(b)

99

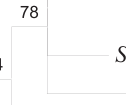

Streptomyces griseorubens NBRC 12780

$59 \quad$ AC-18

Streptomyces tendaeATCC 19812

49 Streptomyces viridochromogenes NBRC 3113

$96 \quad$ Streptomyces ambofaciens ATCC 23877

$96 \longrightarrow$ AC-6

64

25

BS-20

97 BS-19

Bacillus altitudinis strain IHB B 6804

100 Bacillus stratosphericus strain A7

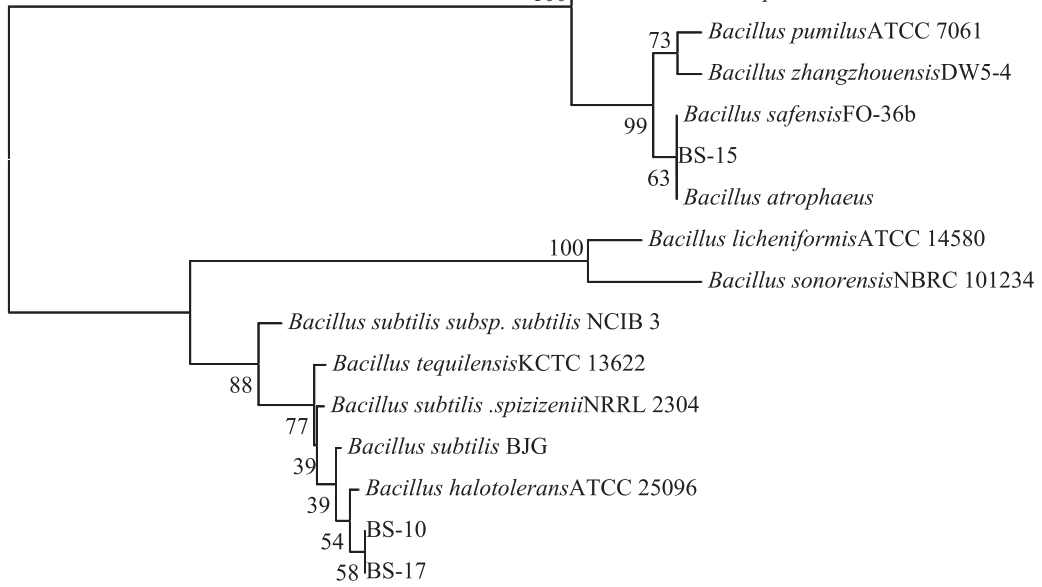

$\stackrel{\longmapsto}{0.001}$ 
B. xiamenensis, B. safensis, B. subtilis, B. altitudinis and B. altitudinis, respectively) (Figure 2(a,b)). The sequences of $16 \mathrm{~S}$ rDNA of AC-5 (1467 bp), AC-6 (1476 bp), AC-10 (1008 bp), AC-18 (1483 bp), AC-19 (1481 bp), BS-10 (1502 bp), BS-15 (1502 bp), BS-17 (1509bp), BS-19 (1499bp) and BS-20 (1488 bp) were submitted to GenBank and accession numbers, MF361862, MF359563, MF359746, MF359734, MF359745, MF359733, MF359735, MF359737, MF370070 and MF370069, respectively, were obtained.

\section{Antagonistic and PGP potentials of the selected Streptomyces and Bacillus isolates under greenhouse conditions}

\section{Antagonistic potentials}

Under greenhouse conditions, when the selected Streptomyces and Bacillus isolates were evaluated for their antagonistic potential against FOC, up to $78 \%$ and $89 \%$ reduction of Fusarium wilt disease incidence, respectively, was observed at 30 DAS over the positive (FOC inoculated) control. In the positive control, $100 \%$ disease incidence was noticed within 20 DAS itself. Of the three method of inoculations, such as seed treatment, soil application and seed treatment + soil application, reduction in Fusarium wilt incidence of up to $44 \%, 78 \%$ and 56\%, respectively, for Streptomyces and up to $88 \%, 89 \%$ and $84 \%$, respectively, for Bacillus isolates were observed. Of the five selected Streptomyces isolates, reduction of disease incidence was found maximum in AC-19 followed by AC-5 and AC-10 whereas for Bacillus isolates, BS-20 followed by BS-19 and BS-15 over the positive control. Both Streptomyces and Bacillus consortia also showed reduction of disease incidence, $11-44 \%$ and $40-55 \%$, respectively, over the positive control (Figure $3(\mathrm{a}, \mathrm{b})$ ).

\section{PGP potentials}

Under greenhouse conditions, at 30 DAS, the selected five Streptomyces and five Bacillus isolates, significantly enhanced plant height (up to 34\% and $27 \%$, respectively), branches number ( $47 \%$ and $47 \%$, respectively), pod number (up to $100 \%$ and $100 \%$, respectively), nodule number $(64 \%$ and $32 \%$, respectively), nodule weight ( $71 \%$ and $81 \%$, respectively), leaf

Figure 2. (a) Phylogenetic relationship between the five FOC antagonistic Streptomyces isolates and representative species based on full length $16 \mathrm{~S}$ rDNA sequences constructed using the neighbour-joining method. The number at each branch is the percentages of times the group of strains in that branch occurred, based on 1000 cycles in bootstrap analysis. (b) Phylogenetic relationship between the five FOC antagonistic Bacillus isolates and representative species based on full length $16 \mathrm{~S}$ rDNA sequences constructed using the neighbour-joining method. The number at each branch is the percentages of times the group of strains in that branch occurred, based on 1000 cycles in bootstrap analysis. 

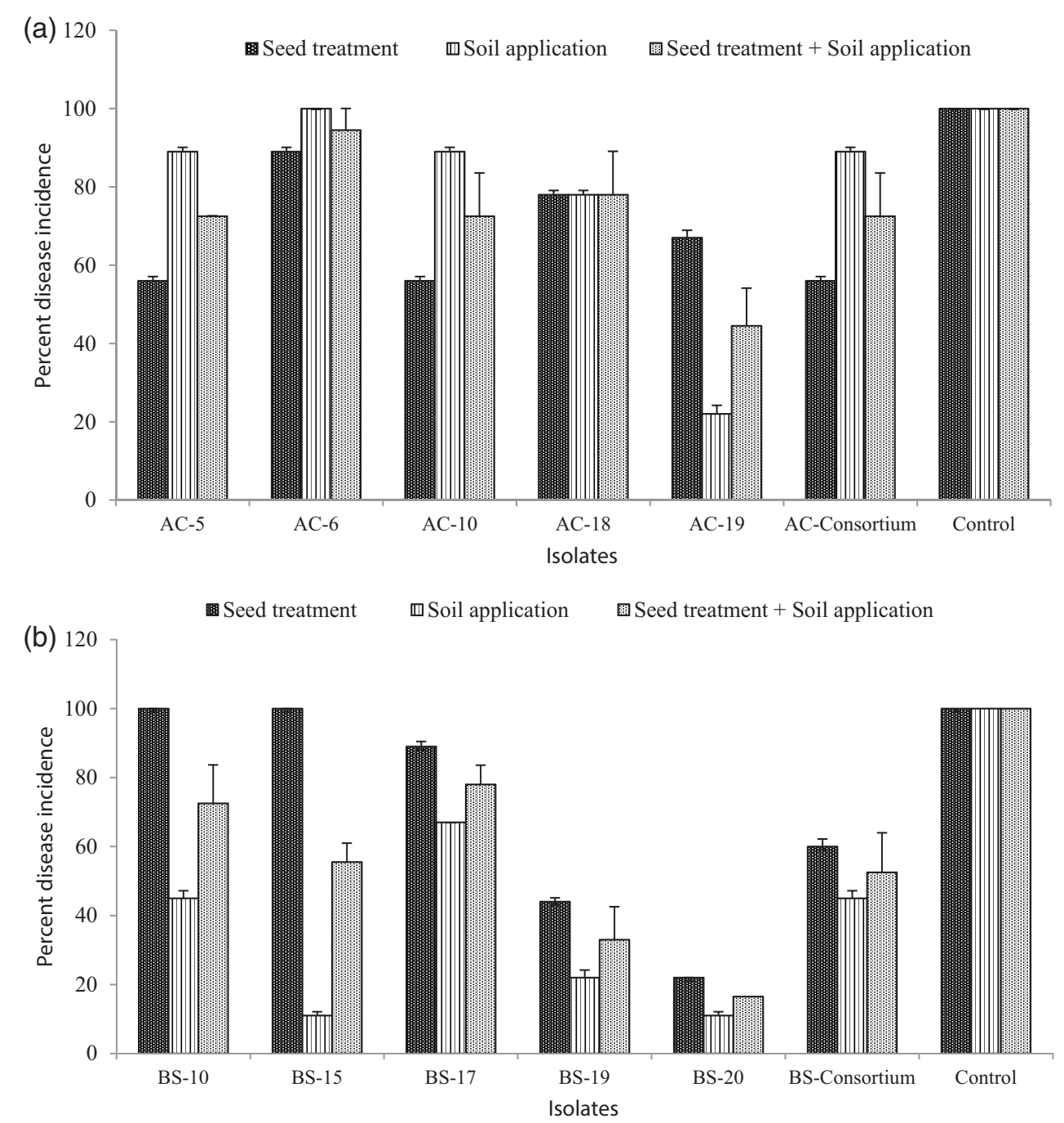

Figure 3. (a) Evaluation of Streptomyces isolates for their antagonistic activity against FOC in wilt sick pots in the greenhouse conditions - at 30 days after sowing. (b) Evaluation of Bacillus isolates for their antagonistic activity against FOC in wilt sick pots in the greenhouse conditions - at 30 days after sowing.

area $(41 \%$ and $60 \%$, respectively), leaf weight $(58 \%$ and $60 \%$, respectively), root weight (56\% and $69 \%$, respectively), stem weight (37\% and $46 \%$, respectively), total plant weight (50\% and $54 \%$, respectively), surface area ( $48 \%$ and $52 \%$, respectively), root length $(42 \%$ and $48 \%$, respectively) and root volume (54\% and 56\%, respectively) over the un-inoculated control. The selected Streptomyces and Bacillus isolates, at 45 DAS, significantly enhanced plant height (23\% and $23 \%$, respectively), branches number ( $42 \%$ and $53 \%$, respectively), nodule number $(50 \%$ and $47 \%$, respectively), nodule weight ( $47 \%$ and $54 \%$, respectively), flower 
number $(100 \%, 100 \%$, respectively), pod number $(100 \%$ and $100 \%$, respectively), root weight (36\% and $33 \%$, respectively), stem weight (51\% and $46 \%$, respectively), leaf weight (30\% and $38 \%$, respectively) and total plant weight $(31 \%$ and $36 \%)$ and while at final harvest, pod number (29\% and $100 \%$, respectively), shoot weight (37\% and $100 \%$, respectively), plant dry weight (27\% and $100 \%$, respectively) seed number $(29 \%$ and $100 \%$, respectively) and seed weight (33\% and $100 \%$, respectively) over the un-inoculated control. Of the five selected Streptomyces isolates, enhanced PGP traits were found maximum in AC-19 followed by AC-5 and AC-10 whereas for Bacillus isolates, BS-20 followed by BS-19 and BS-15 over the un-inoculated control. Both Streptomyces and Bacillus consortium also significantly enhanced all the observed PGP traits at 30 DAS, 45 DAS and final harvest (Tables 2-4).

\section{Antagonistic and PGP potentials of selected Streptomyces and Bacillus isolates under field conditions}

\section{Antagonistic potentials}

Under wilt sick field conditions, when the chickpea cultivar JG62 (early wilter) was used, a reduction of wilt incidence of up to $32 \%$ and $31 \%$ (for Streptomyces and Bacillus isolates, respectively) was observed at 22 DAS over the control (Streptomyces/Bacillus un-inoculated control). When the chickpea cultivar K850 (later wilter) was used, a reduction of wilt incidence of up to $45 \%$ and $32 \%$ (for Streptomyces and Bacillus isolates, respectively) was observed at 45 DAS over the control (Streptomyces/Bacillus un-inoculated control). Reduction of disease incidence was found maximum with AC-19 followed by AC- 5 and AC-10 for Streptomyces and BS- 19 followed by BS-20 and BS-15 for Bacillus isolates while the other four isolates (AC-6, AC-18, BS-10 and BS-17) showed lower levels of reduction of wilt disease incidence in both JG62 and K850 cultivars over the control (Figure 4(a-d)).

\section{PGP potentials}

Under field conditions, when JG11 was used, at 35 DAS, the selected five Streptomyces and five Bacillus isolates, significantly enhanced plant height (up to $16 \%$ and $4 \%$, respectively), nodule number $(53 \%$ and $54 \%$, respectively), nodule weight ( $43 \%$ and $63 \%$, respectively), leaf area ( $40 \%$ and $37 \%$, respectively), leaf weight (52\% and $51 \%$, respectively) and stem weight ( $48 \%$ and $37 \%$, respectively), over the un-inoculated control. The selected Streptomyces and Bacillus isolates, at 60 DAS, significantly enhanced plant height ( $18 \%$ and $15 \%$, respectively), nodule number ( $36 \%$ and $33 \%$, respectively), nodule weight (61\% and $38 \%$, respectively), shoot weight (32\% and 22\%, respectively), pod number ( $49 \%$ and $24 \%$, 


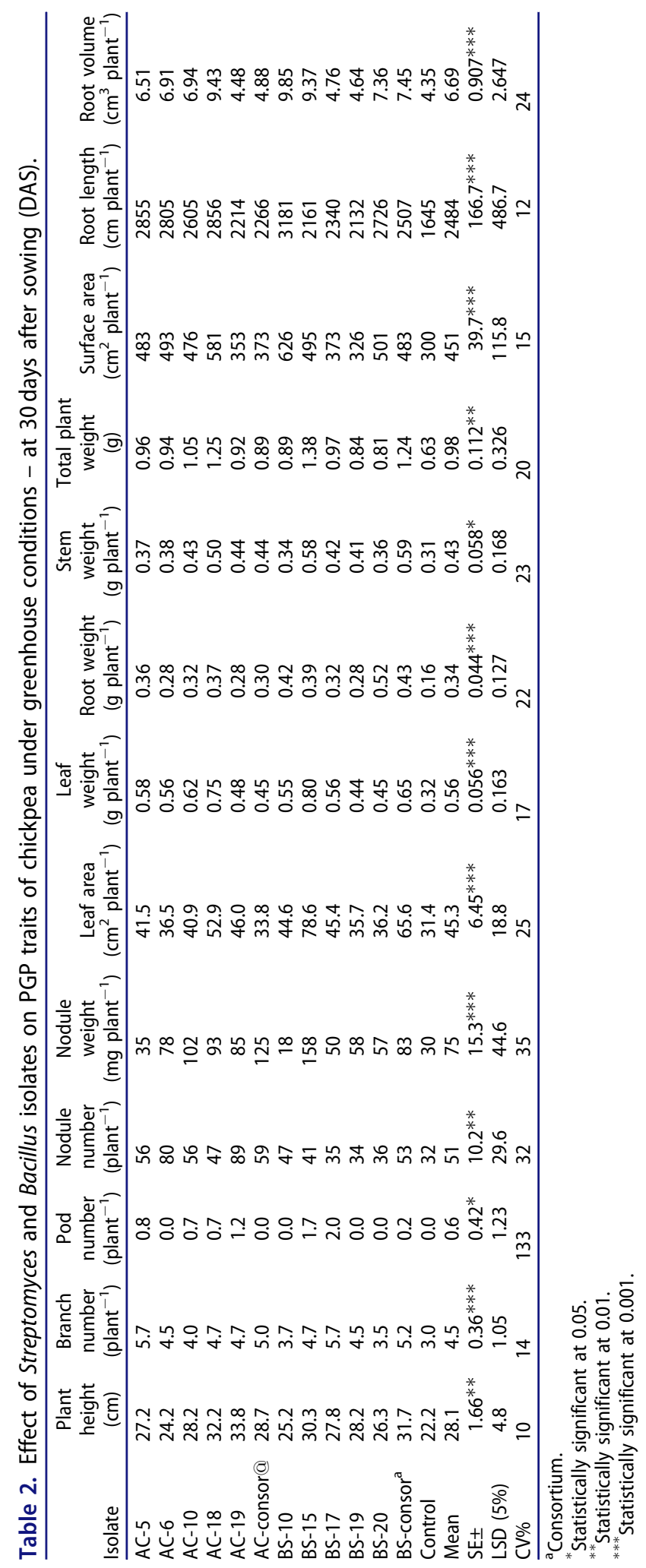




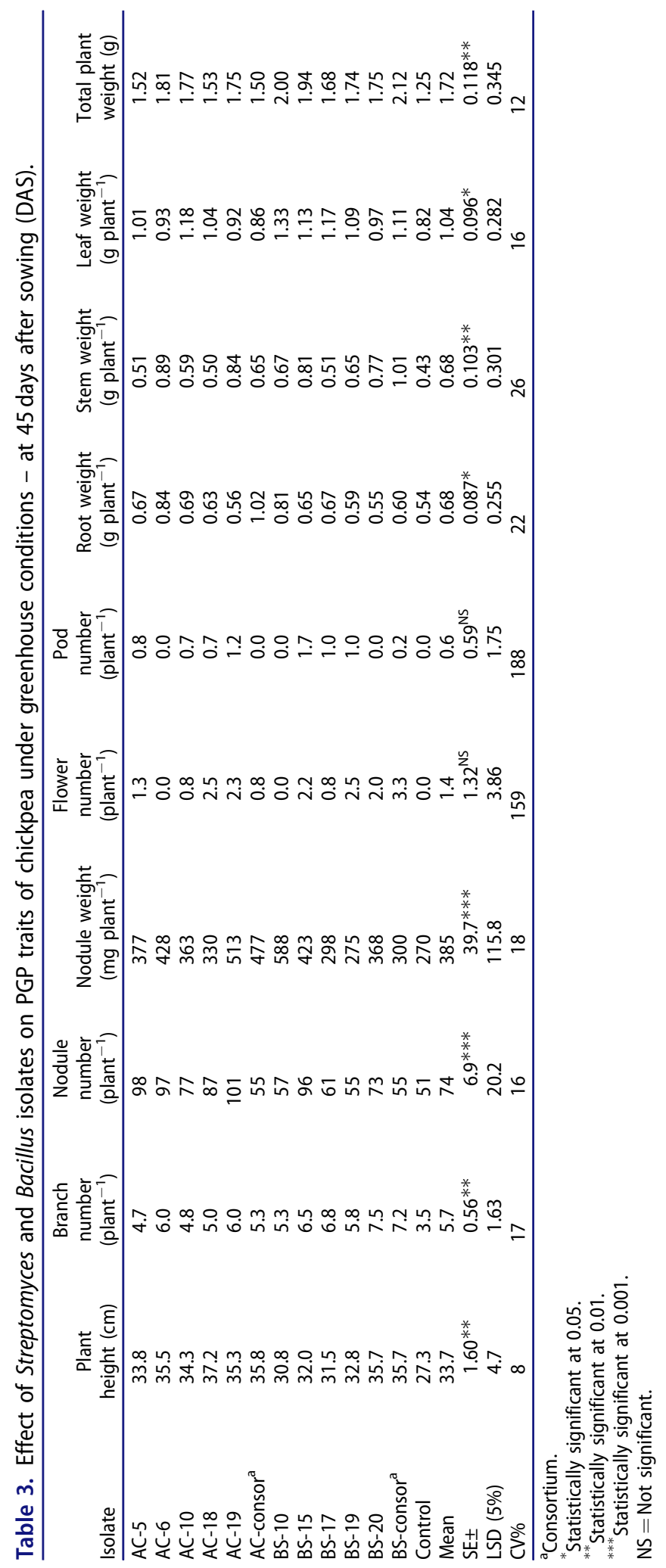


Table 4. Effect of Streptomyces and Bacillus isolates on PGP traits of chickpea under greenhouse conditions - at crop maturity.

\begin{tabular}{lccccc}
\hline Isolate & $\begin{array}{c}\text { Pod number } \\
\left(\text { plant }^{-1}\right)\end{array}$ & $\begin{array}{c}\text { Shoot weight } \\
\left(\mathrm{g} \mathrm{plant}^{-1}\right)\end{array}$ & $\begin{array}{c}\text { Pod dry weight } \\
\left(\mathrm{g} \mathrm{plant}^{-1}\right)\end{array}$ & $\begin{array}{c}\text { Seed number } \\
\left(\text { plant }^{-1}\right)\end{array}$ & $\begin{array}{c}\text { Seed weight } \\
\left(\mathrm{g} \mathrm{plant}^{-1}\right)\end{array}$ \\
\hline AC-5 & 19.7 & 5.25 & 4.81 & 20 & 3.60 \\
AC-6 & 18.0 & 5.24 & 4.56 & 19 & 3.91 \\
AC-10 & 20.7 & 4.97 & 5.17 & 21 & 4.06 \\
AC-18 & 16.0 & 4.55 & 4.20 & 17 & 3.20 \\
AC-19 & 19.3 & 4.57 & 4.76 & 20 & 3.81 \\
AC Consortium & 18.3 & 3.88 & 4.76 & 18 & 3.75 \\
BS-10 & 19.7 & 5.02 & 5.87 & 21 & 4.68 \\
BS-15 & 18.7 & 7.13 & 5.25 & 19 & 3.60 \\
BS-17 & 19.7 & 6.22 & 5.16 & 20 & 3.66 \\
BS-19 & 18.3 & 6.09 & 5.26 & 18 & 3.89 \\
BS-20 & 16.7 & 6.77 & 4.97 & 17 & 3.74 \\
BS Consortium & 26.0 & 4.44 & 5.35 & 26 & 4.45 \\
Control & 14.7 & 3.29 & 3.77 & 15 & 2.74 \\
Mean & 18.9 & 5.19 & 4.91 & 19 & 3.77 \\
SE \pm & $1.83^{*}$ & $0.459^{* * *}$ & $0.323^{*}$ & $1.8 *$ & $0.299^{*}$ \\
LSD (5\%) & 5.4 & 1.34 & 0.942 & 5.2 & 0.873 \\
CV\% & 17 & 15 & 11 & 16 & 14 \\
\hline
\end{tabular}

${ }^{*}$ Statistically significant at 0.05 .

${ }^{* * *}$ Statistically significant at 0.001 .

respectively) and pod weight (64\% and $45 \%$, respectively) and while at final harvest, pod number ( $41 \%$ and $36 \%$, respectively), pod weight ( $42 \%$ and $34 \%$, respectively), seed number ( $41 \%$ and $34 \%$, respectively), stover weight (37\% and 29\%, respectively) and grain yield (34\% and $28 \%$, respectively) over the un-inoculated control. Of the five selected Streptomyces isolates, enhanced PGP traits were found maximum in AC19 followed by AC-5 and AC-10 whereas for Bacillus isolates, BS-19 followed by BS-20 and BS-15 over the un-inoculated control. Both Streptomyces and Bacillus consortium also significantly enhanced all the observed PGP traits at 35 DAS, 60 DAS and final harvest (Tables 5-7). The colonisation of Streptomyces and Bacillus isolates on the roots of chickpea was demonstrated by SEM. Extensive colonisation was observed on the roots of chickpea by all the isolates (Figure 5).

\section{Discussion}

Actinobacteria, Streptomyces in particular, and Bacillus are reported widely for their antagonistic and PGP properties in various crops (Moradi et al. 2012). However, we did not have good biocontrol agents for controlling Fusarium wilt of chickpea. Hence, the present investigation was aimed to isolate these two biocontrol agents from rhizosphere soils of chickpea and to evaluate for their antagonistic potential against FOC and PGP potentials in chickpea. Of the 40 actinomycete and Bacillus isolates tested for their antagonistic potential against FOC by dual-culture assay, only 10 of them (25\%; 5 each of actinomycetes and 

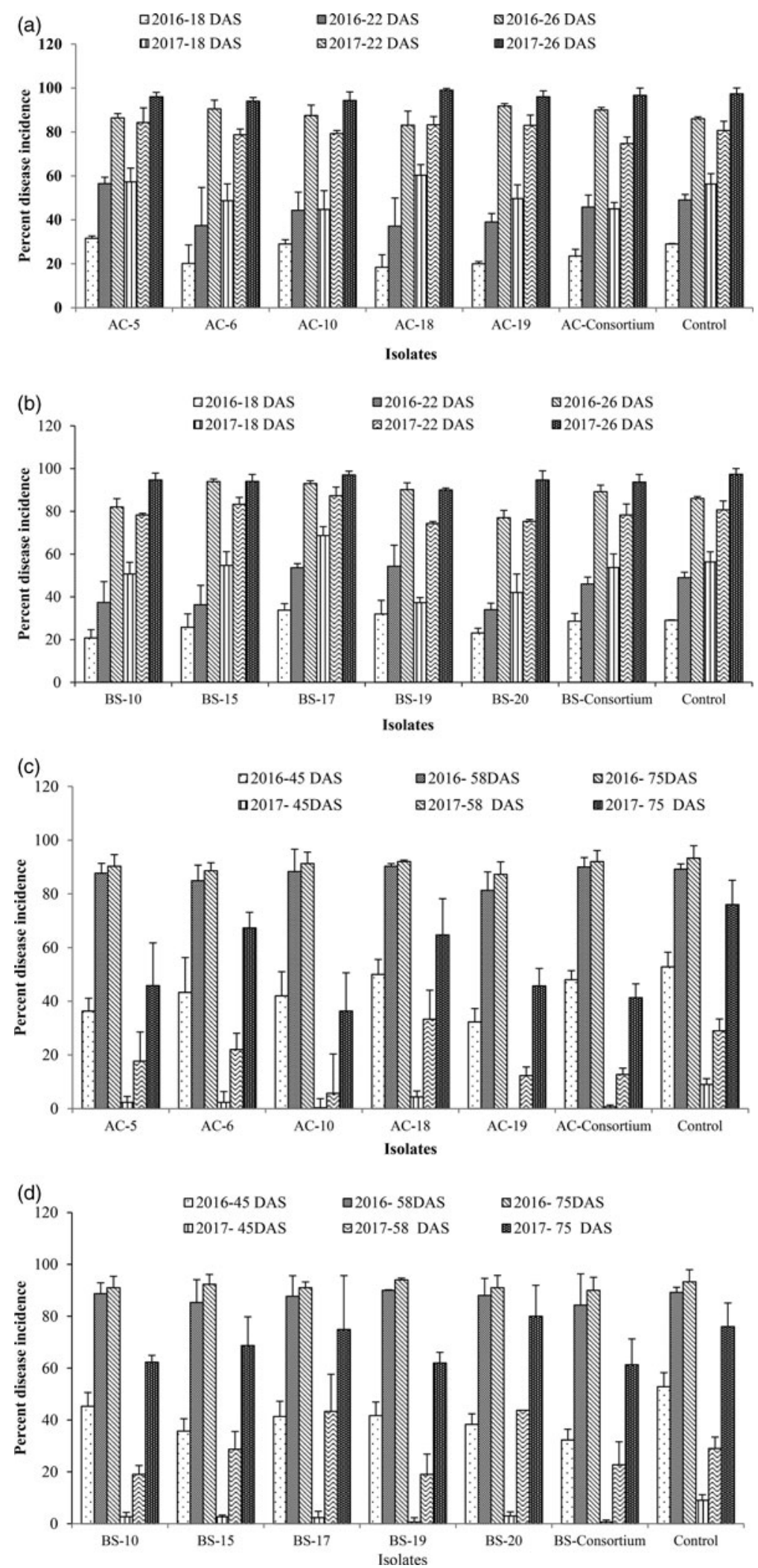
Bacillus) were found to have good antagonistic potential against FOC, of which BS 20 and AC-5 were found to inhibit FOC the most.

In the present study, the selected 10 actinomycete and Bacillus isolates were found to produce IAA, $\beta$-1,3-glucanase, cellulase (except AC-5), protease (except AC-5, AC-10 and BS-10), lipase (except AC-5), HCN (except AC-18 and BS-10) and siderophore (only by four isolates; AC-10, AC-18, BS-15 and BS-20). Of the 10 FOC antagonistic isolates studied, only BS-20 was found to produce all the PGP and biocontrol traits. Microbes producing IAA are known to stimulate seed germination, root formation and increase root surface area and length, thereby providing the host plant greater access to water and soil nutrients, fruit formation and abscission control (Khamna et al. 2009). The ability of microbes to produce extra cellular enzymes such as $\beta$-1,3-glucanase, cellulase, protease and lipase helps in controlling the plant pathogens by acting on their cell walls, thereby indirectly functions as PGP (Chet and Inbar 1994; Lima et al. 1998; Ellis et al. 2000; Lynd et al. 2002; Haas and Defago 2005). HCN production by microbes is reported widely to play a role in disease suppression (Haas et al. 1991; Wei et al. 1991; Siddiqui 2006). Siderophores function as solubilising agents for iron from minerals under conditions of iron limitation and helps to inhibit the growth of plant pathogens (Tokala et al. 2002). Siderophores producing microbes bind $\mathrm{Fe}^{3+}$ from the environment and make it available for its own growth as well as make it available for plants (Wang et al. 2014). In the present study, the selected actinomycetes and Bacillus isolates produced one or more extra cellular enzymes and growth-promoting hormones and hence it can be concluded that these have good biocontrol and PGP potentials (Table 1).

Phylogenetic analysis of $16 \mathrm{~S}$ rDNA sequences of the selected five FOC antagonistic actinomycetes showed that all isolates matched $100 \%$ with Streptomyces but different species while the selected five Bacillus isolates matched 100\% with Bacillus but different species (Figure 2(a,b)). The sequences of the 10 FOC antagonistic bacteria were submitted to GenBank and the cultures to ICRISAT microbial collection bank.

In the present investigation, the five Streptomyces and Bacillus isolates were demonstrated for their antagonistic potentials against FOC under both greenhouse as well as wilt sick field conditions. The germination

Figure 4. (a) Evaluation of Streptomyces isolates for their antagonistic activity against FOC in wilt sick field conditions - on chickpea cultivar JG62. (b) Evaluation of Bacillus isolates for their antagonistic activity against FOC in wilt sick field conditions - on chickpea cultivar JG62. (c) Evaluation of Streptomyces isolates for their antagonistic activity against FOC in wilt sick field conditions - on chickpea cultivar K850. (d) Evaluation of Bacillus isolates for their antagonistic activity against FOC in wilt sick field conditions - on chickpea cultivar K850. 


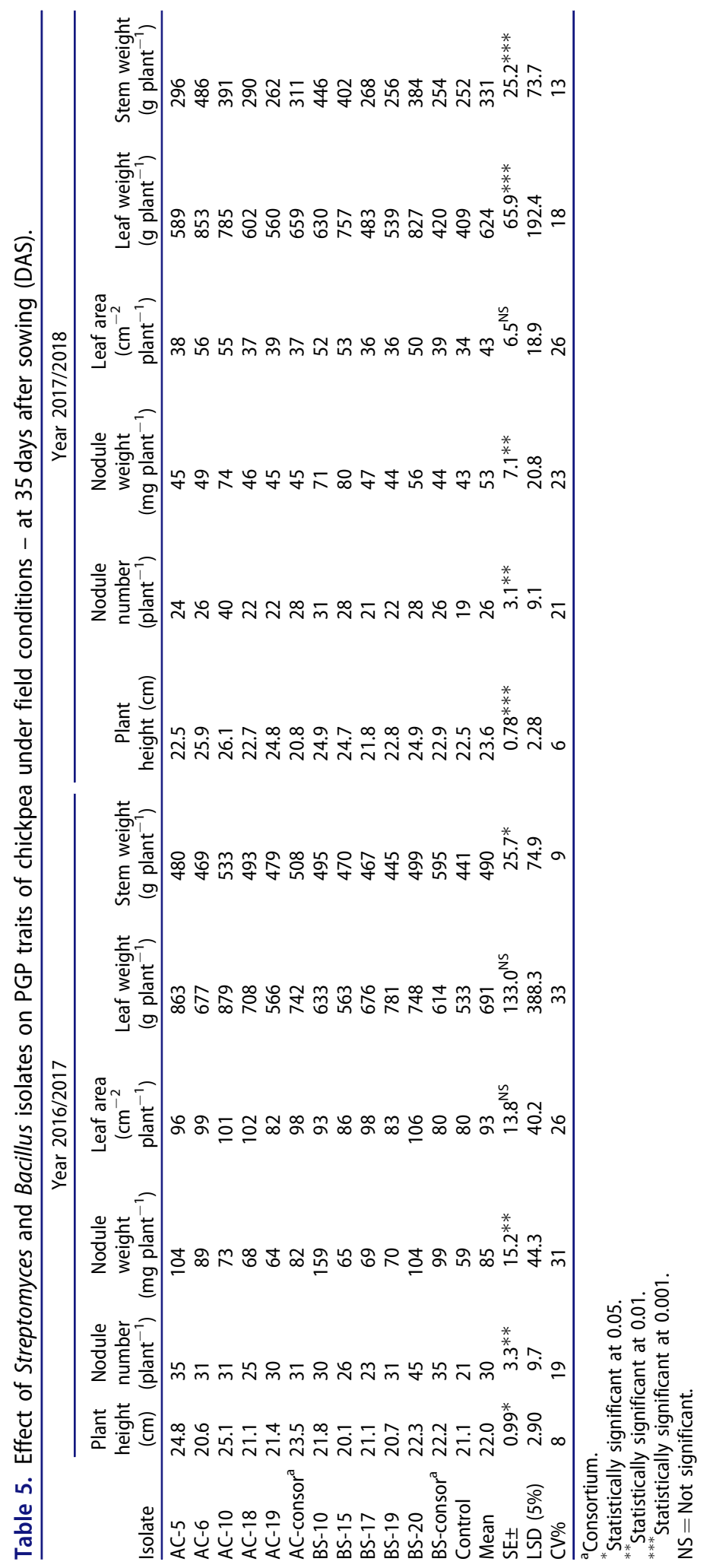




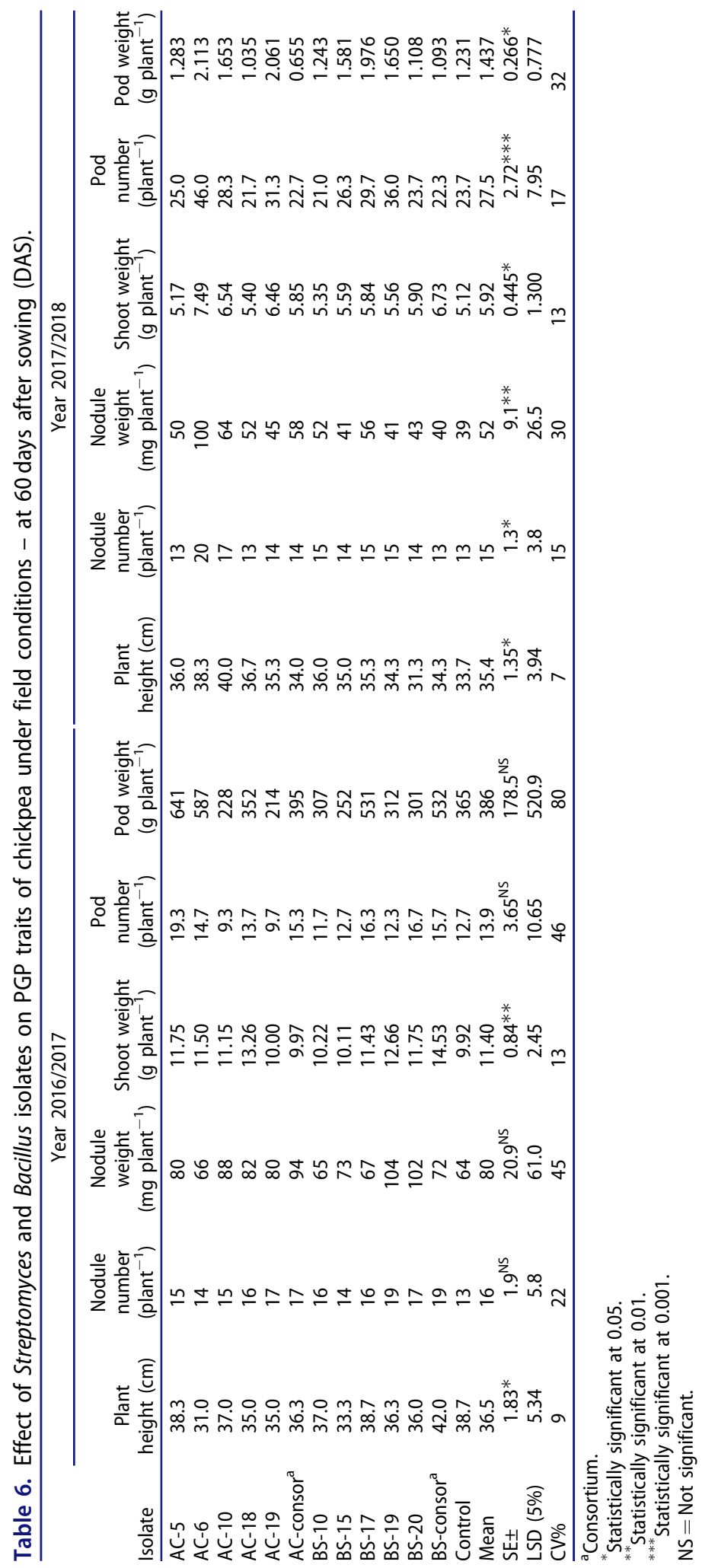




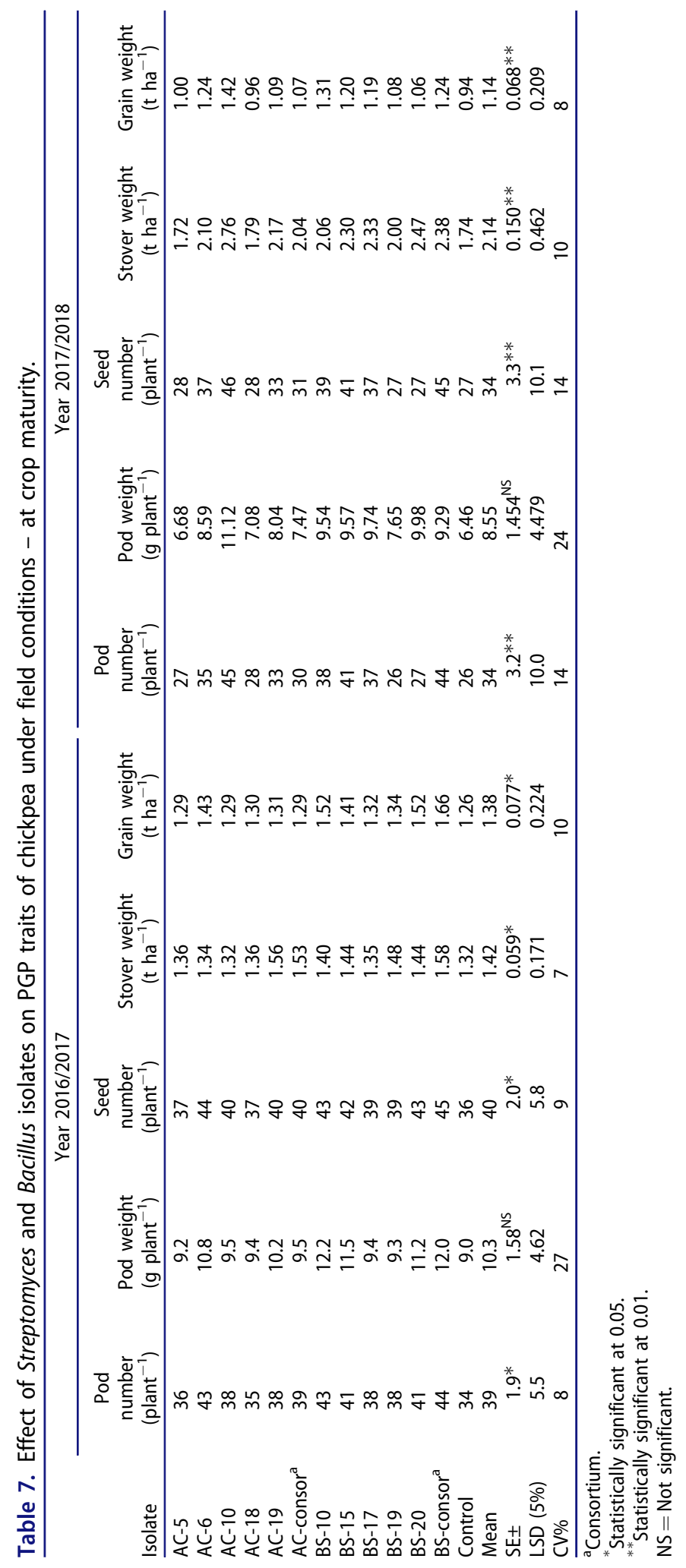




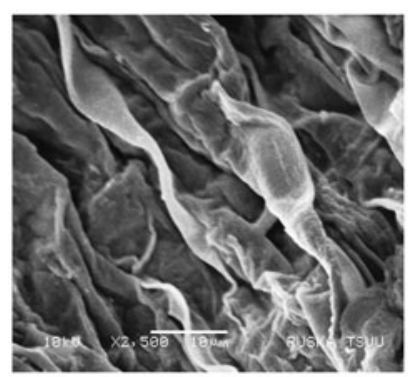

Control

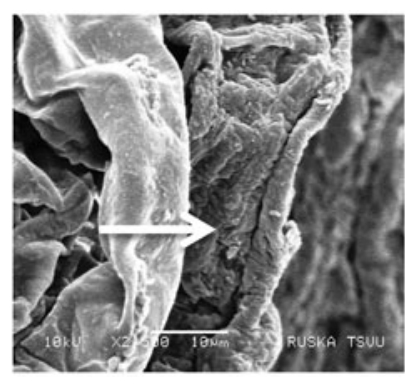

BS-20

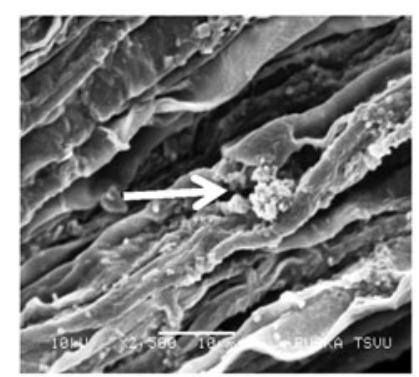

BS-19

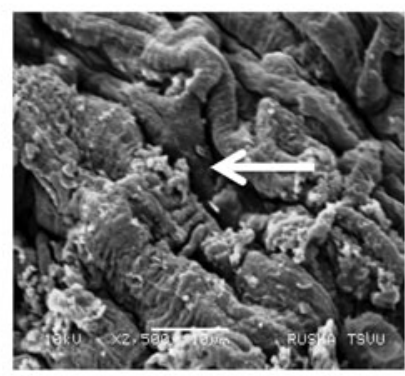

AC-19

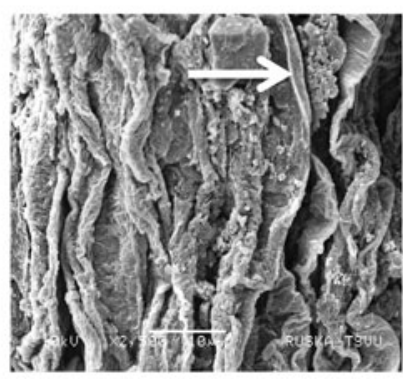

AC-18

Figure 5. Scanning electron microscopy images of chickpea roots colonisation of Streptomyces and Bacillus isolates. Note: Arrows indicate chickpea roots colonised by BS-20, BS-19, AC-19 and AC-18.

percentage of the seeds under both greenhouse and field studies were more than 90\%, 80\% (mean of both JG-62 and K850), respectively, in both test organisms as well as non-inoculated control treatments. Hence, it can be concluded that the test organisms have no negative impact on the germination and growth of chickpea. Of the five selected Streptomyces isolates, reduction of disease incidence was found maximum in AC-19 followed by AC-5 and AC-10 whereas for Bacillus isolates, BS19 followed by BS-20 and BS-15 over the positive control in both greenhouse as well as field conditions (Figure 3(a-d)). Streptomyces spp. have been reported widely to protect crop plants against plant pathogens such as Rhizoctonia solani (causes pea root rot) and F. oxysporum f. sp. cubense (causes wilt in banana) (Rothrock and Gottlieb 1984; Liu et al. 1996; Getha et al. 2005). Streptomyces spp. were also reported to control FOC in chickpea (Bashar and Rai 1994; Nonoh et al. 2010). Bacillus spp. have also been reported widely to protect crop plants against phytopathogens (Boulter et al. 2002; Johri et al. 2003; Saharan and Nehra 2011). The mechanisms involved in biocontrol of plant pathogens by antagonistic bacteria include either by competition (Elad and Chet 1987) or by metabolite production such as siderophore, $\mathrm{HCN}$, antibiotics or extracellular enzymes such as cellulase, chitinase, protease, lipase and $\beta$-1,3-glucanase (Sang et al. 2006; El Hassni et al. 2007; Idris et al. 2007). In the 
present investigation, the selected FOC antagonistic Streptomyces and Bacillus isolates produced many of these extracellular enzymes and $\mathrm{HCN}$, which could have played a role in suppression of FOC.

In the present study, the selected FOC antagonistic Streptomyces and Bacillus isolates were found to significantly enhance PGP traits including nodule number, nodule weight, shoot weight, root weight, pod number, pod weight, seed number, seed weight, gain yield and stover yield under both greenhouse as well as field conditions (Tables 2-7). Bacteria are reported to chemo-attract towards the root exudates, colonise in rhizosphere and played an important role in reducing pathogen population and enhancing plant nutrition (Bulluck et al. 2002; Lugtenberg and Kamilova 2009). Such bacteria, including Streptomyces and Bacillus, are reported widely to enhance not only nodulation and nitrogen fixation but also grain and stover yield in crops, including tomato, wheat, rice, sorghum, bean, pigeonpea and chickpea (Tokala et al. 2002; El-Tarabily et al. 2009; Choudhary and Johri 2009; Sadeghi et al. 2012; Gopalakrishnan et al. 2014, 2015, 2016; Sreevidya and Gopalakrishnan 2017). In the present study, the enhancement of yield and other PGP traits were probably contributed either by IAA or by other hydrolytic enzymes, produced by Streptomyces and Bacillus isolates.

In the present study, under both greenhouse and field conditions, Streptomyces sp. AC-19 and Bacillus sp. BS-20 significantly inhibited FOC and enhanced morphological and yield parameters of chickpea such as plant height, leaf area and weight, stem weight, root length, volume and weight, nodule number, nodule weight, stove yield and grain yield over the un-inoculated control. The mechanism by which the AC-19 and BS-20 inhibited FOC and enhanced the plant growth and yield parameters of chickpea could be attributed to their siderophore, IAA, lipase, protease, $\beta$-1,3-glucanase, $\mathrm{HCN}$ producing capabilities and/or to their ability to survive under harsh environments. Such broad spectrum PGP and biocontrol agents may offer potentially effective novel strategies not only for controlling multiple pathogens and insect pests but also help in conservation of the rapidly eroding agricultural lands. There is a need to do additional comprehensive research for identifying mode of action of AC-19 and BS-20 in controlling Fusarium wilt in chickpea and conduct multi-location trials.

\section{Acknowledgments}

This work has been undertaken as part of the CGIAR Research Program on Grain Legumes and Dryland Cereals. ICRISAT is a member of CGIAR Consortium. We would also like to thank ICRISAT and all of the staff members of the biocontrol unit, including 
P.V.S. Prasad, V. Srinivas, A. Satya, A. Jabbar, A. Sandip and P. Mathur for their significant inputs in the laboratory and field experiments.

\section{Disclosure statement}

No potential conflict of interest was reported by the authors.

\section{References}

Alschul SF, Gish W, Miller W, Myers EW, Lipman DJ. 1990. Basic local alignment search tool. J Mol Biol. 21:403-410.

Anjaiah V, Cornelis P, Koedam N. 2003. Effect of genotype and root colonization in biological control of Fusarium wilts in pigeonpea and chickpea by Pseudomonas aeruginosa PNA1. Can J Microbiol. 49(2):85-91.

Bashar MA, Rai B. 1994. Antagonistic potential of root-region microflora of chickpea against Fusarium oxysporum f. sp. ciceri. Bangla J Bot. 23:13-19.

Bazzicalupo M, Fani R. 1995. The use of RAPD for generating specific DNA probes for microorganisms. In: Clap JP, editor. Methods in molecular biology, species diagnostic protocols: PCR and other nucleic acid methods. Totowa, NJ: Humana Press Inc.; p. $112-124$.

Berdy J. 2012. Thoughts and facts about antibiotics: where we are now and where we are heading. J Antibiot. 65:385-395.

Bhattacharya A, Chandra S, Barik S. 2009. Lipase and protease producing microbes from the environment of sugar beet field. Ind J Agric Biochem. 22:26-30.

Boulter JI, Trevors JT, Boland GJ. 2002. Microbial studies of compost: bacterial identification, and their potential for turf grass pathogen suppression. World J Microbiol Biotech. 18(7):661-671.

Bulluck LR, Brosius M, Evanylo GK, Ristaino JB. 2002. Organic and synthetic fertility amendments influence soil microbial, physical and chemical properties on organic and conventional farms. Appl Soil Ecol. 19(2):147-160.

Cakmakci N, Singh K, Simanth N. 2006. Chickpea with a newly developed quantitative polymerase chain reaction assay. Phytopathology. 1:250-262.

Cao Y, Zhang Z, Ling N, Yuan Y, Zheng X, Shen B, Shen Q. 2011. Bacillus subtilis SQR 9 can control Fusarium wilt in cucumber by colonizing plant roots. Biol Fertil Soils. 47(5):495-506.

Chet I, Inbar J. 1994. Biological control of fungal pathogens. Appl Biochem Biotechnol. 48(1):37-43.

Choudhary DK, Johri BN. 2009. Interactions of Bacillus sp. and plants with special reference to induced systemic resistance (ISR). Microbiol Res. 64:493-513.

Das IK, Indira S, Annapurna A, Prabhakar, Seetharama N. 2008. Biocontrol of charcoal rot in sorghum by fluorescent Pseudomonads associated with the rhizosphere. Crop Prot. 27:1407-1414.

Dubey SC, Suresh M, Singh B. 2007. Evaluation of Trichoderma species against Fusarium oxysporum f. sp. ciceri for integrated management of chickpea wilt. Biol Cont. 40(1):118-127.

Elad Y, Chet I. 1987. Possible role of competition for nutrients in biocontrol of Pythium damping-off by bacteria. Phytopathology. 77(2):190-195. 
El Hassni M, El Hadrami A, Daayf F, Chérif M, Barka EA, El Hadrami I. 2007. Biological control of bayoud disease in date palm: selection of microorganisms inhibiting the causal agent and inducing defense reactions. Environ Exp Bot. 59(2): 224-234.

Ellis RJ, Timms-Wilson TM, Bailey MJ. 2000. Identification of conserved traits in fluorescent Pseudomonads with antifungal activity. Environ Microbiol. 2(3):274-284.

El-Tarabily KA, Nassar AH, Hardy GESJ, Sivasithamparam K. 2009. Plant growth promotion and biological control of Pythium aphanidermatum, a pathogen of cucumber, by endophytic actinomycetes. J Appl Microbiol. 106(1):13-26.

Erdogan O, Benlioglu K. 2010. Biological control of Verticillium wilt on cotton by the use of Fluorescent Pseudomonas sp. under field conditions. Biol Cont. 53(1):39-45.

Getha K, Vikineswary S, Wong WH, Seki T, Ward A, Goodfellow M. 2005. Evaluation of Streptomyces sp. strain G10 for suppression of Fusarium wilt and rhizosphere colonization in pot grown banana plantlet. J Ind Microbiol Biotechnol. 32(1):24-32.

Gopalakrishnan S, Beale MH, Ward JL, Strange RN. 2005. Chickpea wilt: identification and toxicity of 8-O-methyl-fusarubin from Fusarium acutatum. Photochemistry. 66(13):1536-1539.

Gopalakrishnan S, Pande S, Sharma M, Humayun P, Kiran BK, Sandeep D, Vidya MS, Deepthi K, Rupela O. 2011. Evaluation of actinomycete isolates obtained from herbal vermicompost for biological control of Fusarium wilt of chickpea. Crop Prot. 30(8): 1070-1078. -

Gopalakrishnan S, Sathya A, Vijayabharathi R. 2016. Plant growth-promoting actinobacteria. A new avenue for enhancing the productivity \& soil fertility of grain Legumes. Singapore: Springer. ISBN 978-981-10-0705-7

Gopalakrishnan S, Srinivas V, Alekhya G, Prakash B, Kudapa H, Varshney RK. 2015. Evaluation of Streptomyces spp. obtained from herbal vermicompost for broad spectrum of plant growth-promoting activities in chickpea. Org Agric. 5(2):123-133.

Gopalakrishnan S, Vadlamudi S, Bandikinda P, Sathya A, Vijayabharathi R, Rupela O, Kudapa H, Katta K, Varshney RK. 2014. Evaluation of Streptomyces strains isolated from herbal vermicompost for their plant growth-promotion traits in rice. Microbiol Res. 169(1):40-48.

Haas D, Defago G. 2005. Biological control of soil borne pathogens by fluorescent Pseudomonads. Nat Rev Microbiol. 3:307-319.

Hendricks D, Keel C, Laville J, Maurhofer M, Oberhansli T, Schnider U, Défago G. 1995. Secondary metabolites of Pseudomonas fluorescens strain CHA0 involved in the suppression of root diseases. In: Hennecke H, Verma DPS, editors. Advances in molecular genetics of plant-microbe interactions. Amsterdam: Springer; p. 450-456.

Haas D, Keel C, Laville J, Maurhofer M, Oberhansli T, Schnider U, Vosard C, Wuthrich B, Defago G. 1991. Secondary metabolites of Pseudomonas fluorescens strain CHAO involved in the suppression of root diseases. In: Hennecke IH, Verma DPS, editors. Advances in molecular genetics of plant-microbe interactions, vol. I. Dordrecht: Kluwer Academic Publishers; p. 450-456.

Hanane H, Koriko M, Gado T, Hafidi M. 2008. Isolation and characterization of rock phosphate solubilizing actinobacteria from a Togolese phosphate mine. African J Biotechnol. 11:312-320.

Idris HA, Labuschagne N, Korsten L. 2007. Screening rhizobacteria for biological control of Fusarium root and crown rot of sorghum in Ethiopia. Biol Cont. 40(1):97-106.

Johri BN, Sharma A, Virdi JS. 2003. Rhizobacterial diversity in India and its influence on soil and plant health. Adv Biochem Eng Biotechnol. 84:49-89. 
Jiménez-Fernández D, Montes-Borrego M, Jiménez Díaz RM, Navas-Cortés JA, Landa BB. 2015. In planta and soil quantification of Fusarium oxysporum f. sp. ciceris and evaluation of Fusarium wilt resistance in Fusarium oxysporum f. sp. ciceris in the soil through seed transmission. Plant Pathol. 23:3-6.

Jimenez-Gasco MM, Milgroom MG, Jimenez-Diaz RM. 2002. Gene genealogies support Fusarium oxysporum f. sp. ciceris as a monophyletic group. Plant Pathol. 51:72-77.

Khamna S, Yokota A, Lumyong S. 2009. Actinomycetes isolated from medicinal plant rhizosphere soils: diversity and screening of antifungal compounds indole-3-acetic acid and siderophore production. World J Microbiol Biotechnol. 25(4):649-655.

Lynd LR, Weimer PJ, Van ZWH, Pretorius IS. 2002. Microbial cellulose utilization: fundamentals and biotechnology. Microbiol Mol Biol Rev. 66(3):506-577.

Lugtenberg B, Kamilova F. 2009. Plant-growth-promoting rhizobacteria. Annu Rev Microbiol. 63:541-556.

Li Q, Ning P, Zheng L, Huang J, Li G, Hsiang T. 2012. Effects of volatile substances of Streptomyces globisporus JK-1 on control of Botrytis cinerea on tomato fruit. Biol Cont. 61(2):113-120.

Lorck H. 1948. Production of hydrocyanic acid by bacteria. Physiol Plant. 1(2):142-146.

Lima LHC, Marco JL, Felix JR. 1998. Enzimashidroliticasenvolvidas no controlebiologicopormiciparasitisma. In: Melo IS, Azevedo JL, editors. Controlebiologico 11 Jaguraiuna: EMBRAPA-MeioAmbiente; p. 263-304.

Liu L, Kloepper JW, Tuzun S. 1996. Induction of systemic resistance in cucumber against Fusarium wilt by plant growth-promoting rhizobacteria. Phytopathology. 85(6):695-698.

Moradi H, Bahramnejad B, Amini J, Siosemardeh A, Haji-Allahverdipoor K. 2012. Suppression of chickpea (Cicer arietinum L.) Fusarium wilt by Bacillus subtilis and Trichoderma harzianum. Plant Omics J. 5:68-74.

Naureen Z, Adam P, Fauzia YH, Robert MR. 2009. Identification of rice blast disease suppressing bacterial strains from the rhizospheres of rice grown in Pakistan. Crop Prot. 28(12):1052-1060.

Nonoh JO, Wilber L, Daniel M, Rafi H, James K, Presnail Eric S, Matilda AO, Richard B, Paul M, Aggrey BN, et al. 2010. Isolation and characterization of Streptomyces species with antifungal activity from selected national parks in Kenya. African J Microbiol Res. 4:856-864.

On A, Wong F, Ko Q, Tweddell RJ, Antoun H, Avis TJ. 2015. Antifungal effects of compost tea microorganisms on tomato pathogens. Biol Cont. 80:63-69.

Patten CL, Glick BR. 1996. Bacterial biosynthesis of indole-3-acetic acid. Can J Microbiol. 42(3):207-220.

Rothrock CS, Gottlieb D. 1984. Role of antibiosis in antagonism of Streptomyces hydroscopicus var. geldanus to Rhizoctonia solani in soil. Can J Microbiol. 30(12): 1440-1447.

Sadeghi A, Karimi E, Dahaji PA, Javid MG, Dalvand Y, Askari H. 2012. Plant growthpromoting activity of an auxin and siderophore producing isolate of Streptomyces under saline soil condition. World J Microbiol Biotechnol. 28(4):1503-1509.

Siddiqui ZA. 2006. PGPR: prospective biocontrol agents of plant pathogens. In: Siddiqui ZA, editor. PGPR: biocontrol and biofertilization. Dordrecht: Springer; p. 111-142.

Sang M-K, Chiang M-H, Yi E-S, Park K-W, Kim K-D. 2006. Biocontrol of Korean ginseng root rot caused by Phytophthora cactorum using antagonistic bacterial strains ISE13 and KJ1R5. Plant Pathol J. 22(1):103-108. 
Saharan BS, Nehra V. 2011. Plant growth-promoting rhizobacteria: a critical review. Life Sci Med Res. 2011(LSRM-21):1-30.

Saitou N, Nei M. 1987. The neighbor joining method: a new method for reconstructing phylogenetic trees. Mol Biol Evol. 4:406-425.

Schwyn B, Neilands J. 1987. Universal chemical assay for the detection and determination of siderophores. Anal Biochem. 160(1):47-56.

Singh PP, Shin YC, Park CS, Chung YR. 1999. Biological control of Fusarium wilt of cucumber by chitinolytic bacteria. Phytopathology. 89(1):92-99.

Sreevidya M, Gopalakrishnan S. 2017. Direct and indirect plant growth-promoting abilities of Bacillus species on chickpea, isolated from compost and rhizosphere soils. Org Agric. 7(1):31-40.

Trapero Casas A, Jimenez-Diaz RM. 1985. Fungal wilt and root rot disease of chickpea in Southern Spain. Phytopathology. 75(10):1146-1151.

Tokala RK, Strap JL, Jung CM, Crawford DL, Salove MH, Deobald LA, Bailey JF, Morra MJ. 2002. Novel plant-microbe rhizosphere interaction involving Streptomyces lydicus WYEC108 and the pea plant (Pisum sativum). Appl Environ Microbiol. 68(5): 2161-2171.

Thompson JD, Gibsom TJ, Plewniak F, Jeanmougin F, Higgins DG. 1997. The clustal X windows interface: flexible strategies for multiple sequence alignment aided by quality analysis tools. J Physiol Res. 4:25-29.

Vivas A, Biró B, Ruíz-Lozano JM, Barea JM, Azcón R. 2006. Two bacterial strains isolated from a $\mathrm{Zn}$ polluted soil enhance plant growth and mycorrhizal efficiency under Zn toxicity. Chemosphere. 62(9):1523-1533.

Wei G, Kloepper JW, Sadik T. 1991. Induction of systemic resistance of cucumber to Colletotrichum orbiculare by selected strains of plant growth-promoting rhizobacteria. Phytopathology. 81(12):1508-1512.

Wang W, Qiu Z, Tan H, Cao L. 2014. Siderophore production by actinobacteria. Biometals. 27(4):623-631. 